\title{
Grażyna Ancyparowicz
}

Górnośląska Wyższa Szkoła Handlowa im. Wojciecha Korfantego w Katowicach e-mail: sekretariat.rpp@nbp.pl

\section{POLITYKA PIENIĘ̇̇NA JAKO ELEMENT STABILIZACJI RYNKU FINANSOWEGO \\ MONETARY POLICY AS AN ELEMENT STABILIZING THE FINANCIAL SYSTEM}

DOI: $10.15611 /$ pn.2018.531.02

JEL Classification: G01, G21, G28, H12

Streszczenie: Celem niniejszego artykułu jest przedstawienie reakcji głównych banków centralnych (FED, EBC i Banku Anglii) na kryzys finansowy 2008-2009 i następującą po nim uporczywą recesję w realnej sferze gospodarki. W badaniu zastosowano metodę analizy dokumentów banków centralnych dotyczących zarówno klasycznych, jak i niestandardowych instrumentów polityki pieniężnej. Szerzej omówiono duże programy skupu aktywów, zainicjowane w warunkach kryzysowych, które są kontynuowane mimo dobrej koniunktury w gospodarce światowej. Narodowy Bank Polski nie wykorzystywał dotychczas w swej polityce niestandardowych instrumentów polityki pieniężnej, ale może to czynić w określonych prawem okolicznościach dla zarządzania płynnością sektora bankowego w celu wspierania polityki gospodarczej rządu.

Słowa kluczowe: bank centralny, luzowanie ilościowe, duży program skupu aktywów.

Summary: The purpose of this article is the presentation of the response of major central banks (such as FED, ECB and the Bank of England) to the financial crisis of 2008-2009 and the persistent recession in the real economy, which followed the crisis. This article is based on the analysis of documents issued by central banks, concerning both the conventional and unconventional instruments of monetary policy. The paper discusses large scale asset purchase programs, which were implemented in the crisis situation and are still continued in spite of the relatively good current economic situation in the global economy. The National Bank of Poland has not resorted to the unconventional instruments of monetary policy yet, but it is authorized to use such instruments in the legally specified circumstances, to support the economic policy of the government.

Keywords: central bank, quantitative easing, large scale asset purchase programs. 


\section{Wstęp}

Pęknięcie bańki spekulacyjnej niemal zawsze wywołuje panikę wśród inwestorów, która skutkuje żywiołową wyprzedażą instrumentów finansowych i bywa przyczyną upadłości wielu podmiotów gospodarczych. Szczególnie groźna jest upadłość dużego banku inwestycyjnego, zdarzenie to bowiem hamuje na pewien czas akcję kredytową (credit crunch), wskutek czego kryzys finansowy nieuchronnie przenosi się na realną sferę gospodarki. Wprawdzie odbudowa aktywów finansowych dokonuje się stosunkowo szybko, lecz przełamanie recesji trwa długo i wymaga interwencji państwa oraz wsparcia banków centralnych dla działań rządu.

Celem niniejszego artykułu jest przedstawienie reakcji Systemu Rezerwy Federalnej, Europejskiego Banku Centralnego oraz Banku Anglii na kryzys finansowy, którego początek symbolizuje upadek banku inwestycyjnego Lehman Brothers (15 września 2008 r.). W celu przełamania tendencji deflacyjnych zastosowano wtedy zarówno klasyczne, jak i niestandardowe instrumenty polityki pieniężnej. Ta strategia ułatwiła przełamanie recesji i przyczyniła się do wejścia gospodarki światowej w fazę ożywienia, lecz niesie wyzwania na przyszłość.

\section{Ekonomiczne przesłanki niekonwencjonalnej polityki pieniężnej}

W latach 80. XX wieku amerykańskie i zachodnioeuropejskie banki inwestycyjne zaczęły akceptować transakcje o bardzo wysokim ryzyku, a uczciwość emisji akcji danej spółki zeszła na dalszy plan. W pewnej mierze zachęcał je do takiej polityki ówczesny szef amerykańskiego nadzoru bankowego, Todd Conover, który głosił, że instytucje publiczne nie mogą dopuścić do upadku żadnego z wielkich banków, bo nie ma finansowych możliwości wypłaty gwarantowanych depozytów. Na przełomie XX i XXI wieku rynek finansowy funkcjonował już przy tak wysokim poziomie ryzyka, że w publicystyce ekonomicznej określano go mianem casino capitalism $^{1}$. W sferze realnej do kryzysu przyczyniła się polityka administracji Georga Busha Juniora, zachęcająca mieszkańców Stanów Zjednoczonych do nabywania (niezależnie od statusu majątkowego) domów i mieszkań.

Wiosną 2007 r. pękła bańka spekulacyjna na amerykańskim rynku nieruchomości mieszkaniowych, kilka miesięcy później obawa przed „toksycznymi” instru-

1 W pewnej mierze na taki rozwój sytuacji mogło wpłynąć zniesienie w 1999 r. ustawy Glassa-Steagalla zakazującej łączenia bankowości inwestycyjnej (o dużym ryzyku) z depozytowo-kredytową. Zdaniem części komentatorów, takich jak senator Bernie Sanders czy Robert Reich, uchylenie przywołanej ustawy wprost prowadziło do kryzysu. Joseph Stiglitz uważa, że powyższa deregulacja wpłynęła na kryzys jedynie pośrednio, jako element rosnącego kulturowego przyzwolenia na podejmowanie większego ryzyka finansowego. Natomiast Paul Krugman i Ben Bernanke nie dostrzegają istotnego związku przyczynowo-skutkowego, ponieważ ich zdaniem ustawa przyjęta w 1933 r. była anachroniczna względem współczesnych nam instytucji finansowych. 
mentami sekurytyzacyjnymi zabezpieczającymi kredyty hipoteczne sparaliżowała sektor bankowości inwestycyjnej² ${ }^{2}$ Rok później w upadłości znalazły się setki instytucji finansowych w Stanach Zjednoczonych, Europie Zachodniej i w innych regionach świata. Obciążenie sektora finansów publicznych z tytułu realizacji programów interwencyjnych w USA i Europie Zachodniej było tak wielkie, że żaden z krajów dotkniętych kryzysem nie był w stanie utrzymać dyscypliny fiskalnej. Podjęte programy oszczędnościowe, polegające głównie na cięciach wydatków budżetowych i redukcji zatrudnienia, hamowały konsumpcję, negatywnie wpływały na nastroje przedsiębiorców, a tym samym jeszcze bardziej ograniczały szanse przełamania uporczywej recesji. W tej sytuacji próbowano rozwiązać problem na gruncie polityki pieniężnej.

\subsection{Polityka FED, EBC i Banku Anglii podczas kryzysu zaufania}

Banki centralne, w ramach przyjętej strategii, korzystają z wachlarza instrumentów, stosownie do bieżących i prognozowanych uwarunkowań realizacji polityki pieniężnej, a także znaczenia poszczególnych segmentów rynku finansowego w mechanizmie transmisji monetarnej [Ancyparowicz 2017, s. 11-20]. Tradycyjnie rozumiana polityka pieniężna polega na sygnalizowaniu pożądanej (optymalnej z punktu widzenia strategii banku centralnego) wysokości stopy procentowej i dostosowaniu bazy monetarnej do poziomu odpowiadającego tej wysokości. Do bieżącego sterowania rynkiem międzybankowym służą podstawowe operacje otwartego rynku (rzadziej - operacje sterylizujące ${ }^{3}$ ), co dotyczy zarówno operacji warunkowych (repo oraz reverse repo), jak i kredytów, ale papiery wartościowe mogą być także skupowane bądź sprzedawane przez bank centralny w ramach operacji bezwarunkowych (długoterminowych, strukturalnych).

W okresie poprzedzającym kryzys subprime niemal wszystkie główne banki centralne stosowały klasyczne instrumenty polityki pieniężnej w celu bilansowania warunków płynnościowych w sektorze bankowym. Operacje otwartego rynku przeprowadzano wówczas niemal wyłącznie z użyciem własnych bonów, bądź papierów wartościowych o najwyższym ratingu, które znajdowały się w portfelach banków komercyjnych ${ }^{4}$. Polityka ta uległa modyfikacji już w pierwszej fazie kryzysu, gdyż awersja wobec ryzyka zahamowała akcję kredytową (credit crunch) w tak znacznym stopniu, że zagrażało to realnej sferze gospodarki. Strategia banków cen-

2 Bezpośrednią przyczyną załamania koniunktury była zapaść na rynku kredytów hipotecznych wysokiego ryzyka (subprime mortgage), toteż kryzys ten potocznie określa się mianem subprime.

3 W przypadku banków centralnych stosujących w ramach prowadzonej polityki pieniężnej operacje sterylizujące (zmniejszające wpływ operacji banku centralnego na poziom rezerw banków komercyjnych) częstszym przypadkiem jest korzystanie z emisji własnych papierów wartościowych, bądź też przyjmowanie depozytów od kontrahentów banku centralnego, aniżeli stosowanie w tym celu operacji warunkowych.

4 Wyjątkiem był japoński bank centralny (Bank of Japan), od 2001 r. wykorzystujący - obok klasycznych instrumentów polityki pieniężnej - także instrumenty niekonwencjonalne w ramach programu skupu aktywów na rynku pierwotnym. 
tralnych polegała $\mathrm{w}$ tym czasie na zasilaniu sektora bankowego w płynność, a także wydłużaniu terminów zapadalności papierów wartościowych w operacjach otwartego rynku. Równolegle do działań o charakterze antykryzysowym banki centralne obniżyły referencyjne stopy procentowe do poziomu bliskiego zeru (w niektórych przypadkach poniżej tego poziomu), zwiększając w ten sposób stopień ekspansywności polityki pieniężnej5.

Federal Reserve System (FED) starał się kształtować stawkę O/N federal funds rate na optymalnym poziomie, do czego służyły m.in. długoterminowe (permanent) operacje otwartego rynku, stosowane w formie transakcji bezwarunkowych polegających na zakupie dłużnych papierów rządowych. Ponadto FED wykorzystywał również warunkowe transakcje krótkoterminowe (temporary), o zapadalności od 2 do 15 dni, służące do doraźnego regulowania warunków płynnościowych. Niezależnie od programów, które miały na celu zapewnienie instytucjom depozytowo-kredytowym finansowanie na różne terminy zapadalności, FED bezpośrednio zasilał podmioty, które przed kryzysem nie były jego kontrahentami. Podobnie EBC dążył do kształtowania wyznaczanej na rynku stawki O/N (EONIA) w pobliżu podstawowej stopy procentowej, wykorzystując 1-tygodniowe operacje podstawowe (Main Refinancing Operations, MRO). Ich uzupełnienie stanowiły (stosowane w mniejszej skali) operacje 3-miesięczne (Longer-Term Refinancing Operations, LTRO). W przypadku banku centralnego Wielkiej Brytanii (Bank of England) celem operacyjnym było kształtowanie rynkowej stawki O/N (SONIA) na poziomie stopy podstawowej tego banku, z wykorzystaniem głównie 1-tygodniowych (shortterm) operacji warunkowych, w mniejszym stopniu operacji warunkowych o terminach zapadalności od 3 do 12 miesięcy [NBP 2017].

\subsection{Niestandardowe instrumenty polityki pieniężnej}

Po upadku Lehman Brothers (15 września 2008 r.) kryzys finansowy przekształcił się w kryzys ekonomiczny, któremu FED, EBC, a także inne banki centralne starały się zaradzić, mając świadomość, że nominalna stopa procentowa równowagi (referencyjna) ukształtowała się na poziomie tak niskim, że nie można jej było dalej obniżać. Zaobserwowano przy tym wzrost popytu na rezerwy w systemie finansowym, ograniczający redystrybucję płynności pomiędzy instytucjami finansowymi i wpływający na osłabienie zdolności kontrolowania przez bank centralny stóp procentowych na rynku pieniężnym. W ślad za tym pojawiły się zakłócenia w funkcjonowaniu mechanizmu transmisji monetarnej, powodujące niższą od oczekiwanej

5 Polityka ujemnych stóp procentowych (Negative Interest Rate Policy, NIRP) dotyczy stosowania ujemnego oprocentowania w operacjach absorbujących płynność sektora bankowego. Wprowadzenie NIRP stanowiło zazwyczaj uzupełnienie innych niekonwencjonalnych działań tych banków centralnych i miało na celu dodatkowe złagodzenie polityki pieniężnej w warunkach narastającego ryzyka spowolnienia wzrostu gospodarczego na świecie i długotrwałego utrzymywania się inflacji poniżej celu bądź poziomu uważanego przez te banki za pożądany. Więcej na ten temat [World Bank 2015; BIS 2016; Jordan 2016]. 
reakcję większości segmentów realnej sfery gospodarki na impuls monetarny [Cecioni i in. 2011; Labonte 2012]. W tych okolicznościach banki centralne podjęły niekonwencjonalne działania, wykorzystując - uprzednio rzadko stosowane lub niestosowane w ogóle - niestandardowe instrumenty antycyklicznej, ekspansywnej polityki pieniężnej ${ }^{6}$.

FED, prowadząc politykę łagodzenia warunków monetarnych, zmierzał do pobudzenia wzrostu gospodarczego poprzez generowanie popytu, przy równoczesnym dążeniu do utrzymania względnej stabilności cen w amerykańskiej gospodarce. W przypadku EBC do celów pośrednich można zaliczyć dążenie do wspierania akcji kredytowej banków komercyjnych, a także poprawy funkcjonowania mechanizmu transmisji monetarnej. Brytyjski bank centralny, zmierzając do poprawienia płynności sektora bankowego oraz zwiększenia poziomu akcji kredytowej dla przedsiębiorstw, chciał przede wszystkim wykorzystać motoryczną rolę popytu krajowego.

Rezultaty nie były zadowalające, toteż w listopadzie 2008 r. FED (jako pierwszy) zainicjował program skupu aktywów (Large Scale Asset Purchase Programme, LSAP), głównie na rynku aktywów sekurytyzowanych zabezpieczonych wierzytelnościami hipotecznymi (Mortgage Backed Securities, MBS); w mniejszym wymiarze przedmiotem tego etapu programu były papiery emitowane przez rząd amerykański oraz jego agendy. Drugi etap programu LSAP, w którym FED powiększył posiadany portfel aktywów krajowych, rozpoczął się w listopadzie $2010 \mathrm{r}$. i objął wyłącznie obligacje rządowe. Trzecia, analogiczna edycja programu LSAP rozpoczęła się we wrześniu 2012 r. i trwała do października 2014 r. Objęte nią zostały papiery typu MBS oraz obligacje rządowe. Uzupełnieniem programu LSAP był, realizowany w okresie październik 2011 r. - grudzień 2012 r., program Maturity Extention Program and Reinvestment Policy (MEP), przy wykorzystaniu którego wydłużony został okres zapadalności papierów wartościowych.

Zgodnie z decyzją Rady Gubernatorów FED (15 marca 2017 r.) w bilansie $\mathrm{Fe}$ deral Reserve System utrzymywana ma być wartość portfela aktywów zakupionych w latach 2008-2014 w ramach trzech rund programu luzowania ilościowego LSAP oraz nabytych w wyniku realizacji Maturity Extension Program and Reinvestment

${ }^{6}$ Niekonwencjonalne działania banku centralnego ukierunkowane na pobudzenie akcji kredytowej polegają w szczególności na: bezpośrednim zaangażowaniu banku centralnego jako podmiotu de facto funkcjonującego na rynku kredytowym oraz bezpośrednim kredytowaniu sektora niefinansowego w warunkach niesprawności mechanizmów rynku finansowego [Lenza i in. 2010; Joyce i in. 2011]. Bernanke [2012] wyróżnia trzy rodzaje niestandardowych działań banków centralnych: zarządzanie oczekiwaniami inflacyjnymi (expectation management) poprzez komunikowanie się z rynkiem o projektowanej wysokości podstawowych stóp procentowych; rozszerzenie pasywów bilansu banku centralnego ponad poziom potrzebny do osiągnięcia zerowych stóp procentowych (quantitative easing); luzowanie jakościowe (qualitative easing) poprzez zmianę struktury bilansu i względnej podaży wybranych rodzajów papierów wartościowych na rynku. P. Morgan [2009], nawiązując do tej klasyfikacji, wyróżnił dwa sposoby prowadzenia polityki antycyklicznej przez bank centralny: operacje refinansujące o wydłużonych terminach zapadalności oraz skup aktywów. 
Policy (MEP). Wskazana decyzja wymaga dokonywania reinwestycji części kapitałowej zapadających aktywów, lecz czas realizacji tej decyzji nie został precyzyjnie określony i zależy od parametrów innych instrumentów polityki pieniężnej FED. Łączna wartość wszystkich portfeli wymienionych wyżej kategorii papierów wartościowych wynosiła na dzień 1 marca 2017 r. 4240 mld USD (95\% łącznej sumy aktywów FED).

W styczniu 2009 r. brytyjski bank centralny zainicjował program Asset Purchase Facility (APF); w marcu tego samego roku skupem objęte zostały głównie papiery emitowane przez rząd brytyjski (gilts), w mniejszym wymiarze także obligacje przedsiębiorstw oraz inne komercyjne papiery wartościowe (Secured Commercial Paper, SCP). Skup aktywów, prowadzący do wzrostu sumy bilansowej banku centralnego Wielkiej Brytanii, dokonywany był z przerwami. Ostatni rozpoczęty został w sierpniu $2016 \mathrm{r}$. w następstwie wyników referendum w sprawie członkostwa Wielkiej Brytanii w Unii Europejskiej i był realizowany w 2017 r. Program ten miał na celu powiększenie utrzymywanego portfela papierów emitowanych przez rząd centralny o 435 mld funtów brytyjskich (po ok. 60 mld GBP miesięcznie), a także zakup obligacji przedsiębiorstw do wysokości 10 mld GBP. Bank centralny Wielkiej Brytanii nie podał do wiadomości publicznej terminu, w jakim ma zamiar osiągnąć zakładany poziom aktywów w swoim portfelu.

Europejski Bank Centralny, równolegle do operacji wykorzystywanych w okresie przedkryzysowym, zdecydował się na wprowadzenie (w ograniczonej skali) programów skupu wybranych aktywów. Należały do nich Covered Bond Purchase Programme (CBPP1 oraz CBPP 2), którymi objęte zostały obligacje zabezpieczone (covered bonds), a także Securities Market Programme (SMP), dedykowany papierom skarbowym wybranych krajów strefy euro. W przypadku EBC za moment rozpoczęcia dużego programu skupu aktywów należy przyjąć rozpoczęcie trzeciej edycji programu dedykowanego rynkom zabezpieczonych obligacji emitowanych przez banki (Covered Bonds Purchase Programme 3, CBPP3), który w listopadzie 2014 r. został uzupełniony o Asset Backed Securities Purchase Programme (ABSPP). W marcu 2015 r. zainicjowano kolejny program (Public Sector Purchase Programme, PSPP), który objął papiery emitowane przez podmioty sektora publicznego krajów należących do Unii Walutowej. Decyzją Rady Prezesów EBC instrument ten określono mianem expanded Asset Purchase Programme (eAPP). W czerwcu 2016 r. program eAPP rozszerzono o segment dłużnych papierów korporacyjnych emitowanych przez przedsiębiorstwa ze strefy euro - Corporate Sector Purchase Programme (CSPP).

\subsection{Program pożyczania aktywów}

Działaniami uzupełniającymi w stosunku do realizowanych obecnie dużych programów skupu aktywów przez banki centralne są programy czasowego pożyczania aktywów (securities lending), które służą poprawie płynności wybranych rynków papierów wartościowych. Prekursorem tej formy interwencji na rynku finansowym 
był FED, który operacje o tym charakterze prowadził już w latach 60 . ubiegłego wieku. Doświadczenia te wykorzystał do odbudowy zaufania do rynku finansowego po kryzysie subprime. Było to tym bardziej zasadne, że już w okresie przedkryzysowym prowadził on politykę opartą na przeprowadzaniu transakcji bezwarunkowego kupna aktywów z wykorzystaniem papierów emitowanych przez rząd federalny. Posiadał więc zasób (tzw. portfel SOMA) niezbędny do zastosowania operacji pożyczkowych. Obecnie transakcje pożyczania aktywów (SOMA securities lending) polegają na wymianie na termin $\mathrm{O} / \mathrm{N}$ posiadanych przez kontrahentów FED wybranych papierów wartościowych (m.in. bonów, obligacji oraz papierów wartościowych indeksowanych do wskaźnika inflacji). Operacje te przeprowadzane są $\mathrm{w}$ formie przetargów.

Program pożyczania aktywów stosowany w Wielkiej Brytanii jest realizowany od sierpnia 2009 r., przy czym zadaniem brytyjskiego banku centralnego jest udostępnianie aktywów, ale transakcje przeprowadza brytyjska agencja zarządzania długiem (Debt Management Office, DMO). Przesłanką zastosowania programu Gilt Lending było uruchomienie przez brytyjski bank centralny w styczniu 2009 r. wspomnianego wyżej programu skupu aktywów (Asset Purchase Facility, APF), który w przeważającej mierze dotyczył długoterminowych papierów emitowanych przez rząd Wielkiej Brytanii (gilts). Należy odnotować, że uczestnictwo brytyjskiego banku centralnego nie wpływa na poziom aktywów utrzymywanych w ramach portfela APF, bo DMO jest zobowiązana do dostarczenia ekwiwalentu papierów wartościowych w miejsce wykorzystanych w ramach programu pożyczania aktywów. Programem pożyczania aktywów objęta została ekskluzywna grupa kontrahentów DMO, którzy zyskali możliwość czasowego pozyskiwania przedmiotowych papierów rządowych poprzez uczestnictwo w regularnych (jednotygodniowych) operacjach, w ramach zarządzania długiem publicznym.

EBC wykorzystuje program pożyczania aktywów od kwietnia $2015 \mathrm{r}$. Jako przesłankę uruchomienia tego programu bank ten wskazał zapewnienie warunków do efektywnego funkcjonowania rynków papierów wartościowych objętych programem eAPP oraz rynku transakcji warunkowych, w przypadku którego wskazane aktywa stanowią zabezpieczenie. Transakcje wypożyczania aktywów zakupionych w ramach programu eAPP realizowane są w sposób zdecentralizowany przez poszczególne banki centralne Eurosystemu. W większości przypadków transakcje wypożyczania aktywów zakupionych w ramach programów płynnościowych przeprowadzane są przy udziale agentów zewnętrznych. Szczegóły dotyczące parametrów programu, takich jak rodzaj aktywów, cena, a także kontrahenci dopuszczeni do przeprowadzania transakcji, określane są przez poszczególne banki centralne Eurosystemu. Należy zwrócić uwagę, iż wspólnym dla Eurosystemu programem pożyczania aktywów objęte są aktywa nabyte w ramach programów Public Sector Purchase Programme (PSPP) oraz Corporate Sector Purchase Programme (CSPP). Dodatkowo część banków centralnych należących do Eurosystemu udostępnia również aktywa zakupione w ramach programów CBPP 1, 2 oraz 3, a także SMP. 


\section{Skup komercyjnych papierów wartościowych w ramach programów interwencyjnych Eurosystemu oraz Banku Anglii}

\subsection{Uwarunkowania prawne}

Traktat o funkcjonowaniu Unii Europejskiej w art. 123 (dawny art. 101 Traktatu ustanawiającego Unię Europejską) stanowi: Zakazane jest udzielanie przez Europejski Bank Centralny lub banki centralne Państw Członkowskich, zwane dalej „krajowymi bankami centralnymi”, pożyczek na pokrycie deficytu lub jakichkolwiek innych kredytów instytucjom, organom lub jednostkom organizacyjnym Unii, rzadom centralnym, władzom regionalnym, lokalnym lub innym władzom publicznym, innym instytucjom lub przedsiębiorstwom publicznym Państw Członkowskich, jak również nabywanie bezpośrednio od nich przez Europejski Bank Centralny lub krajowe banki centralne ich papierów dtużnych. Regulacja ta została również ujęta w art. 21 Statutu ESBC/EBC 7 , ale art. 18 ust. 1 określa sytuacje, w których norma ta nie obowiązuje: aby osiagnać cele ESBC $i$ wykonywać swe zadania, EBC i krajowe banki centralne moga dokonywać operacji na rynkach finansowych $w$ formie kupna i sprzedaży bezwarunkowej (outright).

Na tej podstawie 10 marca 2016 r. Rada Prezesów EBC ogłosiła zmianę w realizacji polityki pieniężnej w celu dalszego łagodzenia warunków monetarnych w strefie euro, m.in. w drodze skupu obligacji emitowanych przez podmioty niebankowe (przedsiębiorstwa) zlokalizowane w tej strefie. W komunikacie z 21 kwietnia tego samego roku Rada określiła kryteria kwalifikowalności aktywów będących przedmiotem skupu w ramach Corporate Sector Purchase Programme - CSPP [Guideline EU 2015/510] oraz poinformowała, że skupione obligacje korporacyjne będą oferowane w ramach programu securities lending ${ }^{8}$.

7 Zakres obowiązywania zakazu finansowania podmiotów gospodarczych ze środków banku centralnego został doprecyzowany w Rozporządzeniu Rady (WE) nr 3603/93 z dnia 13 grudnia 1993 r. W szczególności art. 8 ww. rozporządzenia określa cechy przedsiębiorstwa publicznego. Jest to podmiot, na który państwo lub inne władze regionalne czy lokalne mogą bezpośrednio lub pośrednio wywierać wpływ dominujący z racji swej własności, udziału kapitałowego lub rządzących nim zasad. Dominacja władz publicznych przejawia się tym, że władze te bezpośrednio lub pośrednio: są w posiadaniu większej części subskrybowanego kapitału przedsiębiorstwa; kontrolują większość głosów związanych z akcjami wyemitowanymi przez przedsiębiorstwo; są w stanie nominować ponad połowę członków administracyjnego, kierowniczego lub nadzorczego organu przedsiębiorstwa. W tym kontekście należy również wspomnieć o ograniczeniach wynikających z zakazu udzielania pomocy przedsiębiorstwom (w tym bankom) w formie ich kredytowania przez bank centralny (czyli m.in. poprzez nabywanie ich papierów dłużnych) w sytuacji, gdy te są niewypłacalne. Takie finansowanie (pomoc) jest uznawane za zadanie przypisane rządom państw członkowskich, a ewentualna jego realizacja przez bank centralny byłaby uznana za finansowanie rządu.

8 Skup obligacji korporacyjnych stanowi uzupełnienie realizowanych wcześniej programów skupu aktywów, prowadzonych w szczególności w ramach programu eAPP. Jego celem - zgodnie z wyżej przywołanym komunikatem - jest wspieranie akomodacyjnej polityki pieniężnej banku centralnego, 
W nawiązaniu do tej deklaracji 1 czerwca 2016 r. zapadła Decyzja [EBC/2016/26] w sprawie uruchomienia programu zakupu komercyjnych papierów wartościowych posiadających rating kredytowy (również na rynku pierwotnym, z wyłączeniem obligacji emitowanych przez podmioty zaliczane do sektora publicznego) ${ }^{9}$. Tydzień później program ten wszedł $\mathrm{w}$ fazę realizacji, a uczestniczy w nim wybrana grupa banków centralnych Eurosystemu ${ }^{10}$, odpowiedzialnych za nabywanie komercyjnych papierów wartościowych pochodzących z przyporządkowanej do nich grupy krajów strefy euro (Banco de España, Banca d'Italia, Banque de France, Deutsche Bundesbank, Banque Nationale de Belgique, Suomen Pankki). Banki te mają autonomię w zakresie wyboru trybu dokonywania transakcji (w ramach rynku wtórnego skup może być realizowany przy wykorzystaniu platformy elektronicznej lub w ramach bezpośredniego kontaktu z kontrahentem). Rada Prezesów EBC nie określiła docelowej wartości programu (wolumenu obligacji), jaki zamierza skupić, jedynie w komunikacie z 26 października 2017 r. powiadomiła, że skup komercyjnych papierów dłużnych będzie prowadzony przynajmniej do września 2018 r. Termin ten został już wydłużony.

\subsection{Skala programu CSPP}

Podstawowym parametrem programu CSPP jest planowana miesięczna wartość skupu aktywów. Od marca 2015 r. do marca 2016 r. skup aktywów w ramach eAPP wyniósł 60 mld euro miesięcznie, od kwietnia 2016 r. do marca 2017 r. -80 mld euro, od kwietnia 2017 r. do grudnia 2017 r. - 60 mld euro, a począwszy od stycznia 2018 r. miesięczna skala skupu (łącznie dla wszystkich segmentów eAPP) została zredukowana do 30 mld euro. Od momentu zainicjowania programu udział CSPP w łącznej skali przyrostu aktywów netto objętych programem eAPP zwiększał się z 10\% do 19\% w styczniu 2018 r., przy spadku udziału aktywów nabywanych w ramach PSPP z 85\% do 69\%. W ujęciu wartościowym portfel pierwszej kategorii ak-

pobudzenie wzrostu gospodarczego oraz przywrócenie inflacji na ścieżkę celu inflacyjnego EBC (nieznacznie poniżej 2\% w średnim okresie). Transakcje tego typu (włączone do katalogu instrumentów polityki pieniężnej w strefie euro) mogą prowadzić inne kraje (w tym Polska) po uzyskaniu pozytywnej opinii władz EBC. Mówi o tym art. 2 ust. 2 Decyzji Rady Prezesów EBC nr 415/98 z 29 czerwca 1998 r. w sprawie konsultacji Europejskiego Banku Centralnego udzielanych władzom krajowym w sprawie projektów przepisów prawnych $(98 / 415 / \mathrm{WE})$.

9 Rating kredytowy na poziomie inwestycyjnym odnosi się do emitenta/instrumentów dłużnych; według Fitch Ratings oraz S\&P poziom inwestycyjny określany jest w skali od AAA do BBB- (lub odpowiedni w przypadku innej agencji ratingowej). Ponadto Rada Prezesów EBC już wcześniej wyróżniła inne kryteria: okres pozostający do zapadalności obligacji w momencie skupu od 6 miesięcy do 30 lat i 364 dni, waluta emisji - EUR, rating kredytowy przyznany przynajmniej przez jedną agencję ratingową na poziomie inwestycyjnym, miejsce emisji obligacji - kraje strefy euro [Guideline ECB, 9 July 2014; Guideline ECB/2007/9; Guideline ECB 2015/510].

${ }^{10}$ Wyłącznymi kontrahentami transakcji zawieranych na rynku wtórnym obligacji korporacyjnych w ramach CSPP są podmioty uprawnione do uczestnictwa w operacjach polityki pieniężnej, które spełniają kryteria kwalifikacji Eurosystemu (udział w rezerwie obowiązkowej, podleganie nadzorowi, dobra kondycja finansowa). 
tywów wzrósł o 5,6 mld euro, drugiej - o 20,9 mld euro, ich wartość bowiem (z uwagi na umorzenie walorów, których termin zapadalności właśnie mijał) w bilansie banków centralnych Eurosystemu przyrastała średnio w miesiącu odpowiednio o 6,5 mld euro oraz 54,8 mld euro.

W przypadku Banku Anglii skup papierów wartościowych emitowanych przez przedsiębiorstwa odbywa się w ramach programu Corporate Bond Purchase Scheme (CBPS) uruchomionego we wrześniu 2016 r. w ramach „dużego” programu skupu aktywów Asset Purchase Facility (APF), realizowanego (z przerwami) od 2009 r. Skup obligacji korporacyjnych realizowany przez Bank Anglii - zgodnie z jego oficjalnym stanowiskiem - ma stymulować popyt (zmniejszając awersję do ryzyka), po to aby obniżyć rentowność papierów emitowanych przez przedsiębiorstwa i tym samym zmniejszyć koszt finansowania tego sektora. Obligacje korporacyjne mogą być nabywane wyłącznie od podmiotów dopuszczonych do udziału w operacjach otwartego rynku (money makers in corporate bonds), posiadających dostęp do elektronicznego systemu Banku Anglii obsługującego tego rodzaju transakcje. Według pierwotnych zamierzeń skup obligacji emitowanych przez przedsiębiorstwa miał sięgnąć 10 mld GBP, ale gdy w maju 2017 r. limit ten został wyczerpany, brytyjski bank centralny zdecydował się na kontynuację skupu w zakresie umożliwiającym utrzymanie wartości tego portfela, co oznacza reinwestycję środków z walorów zapadających [Quarterly Bulletin 2017 Q3].

\subsection{Prawne możliwości interwencji NBP na rynku pieniężnym}

Inicjując jesienią 1989 r. reformę polskiego systemu bankowego, podjęto decyzję, że w gestii banku centralnego mają pozostać czynności związane z działalnością emisyjną, kształtowaniem polityki pieniężnej oraz pełnieniem funkcji banku banków i banku państwa. Wydzielając z Narodowego Banku Polskiego dziewięć banków komercyjnych, wyłączono z zakresu uprawnień NBP czynności związane z bezpośrednim kredy towaniem i kontrolą przedsiębiorstw. Ustawa o NBP z $1997 \mathrm{r}$. w art. 3 ust. 1 stwierdza, że podstawowym celem działalności polskiego banku centralnego jest utrzymanie stabilnego poziomu cen, lecz - jeśli nie wpłynie to negatywnie na główny zakres odpowiedzialności NBP - bank ten może realizować cel pomocniczy, jakim jest wspieranie polityki gospodarczej rządu. Realizując te cele, NBP kieruje swoje instrumenty tylko do instytucji monetarnych, nie może natomiast kupować obligacji ani innych papierów wartościowych na rynku pierwotnym. Stosownie do art. 48 pkt 2 ustawy o NBP walory te mogą być przedmiotem transakcji na rynku krajowym w ramach operacji otwartego rynku, pod warunkiem że zastosowanie tego instrumentu przewidziano w Założeniach Polityki Pieniężnej na dany rok. W zakresie zarządzania rezerwami dewizowymi (art. 52 ustawy o NBP) ograniczenia te nie występują, gdyż obowiązują tu normy prawne Unii Europejskiej dotyczące podmiotów publicznych oraz pomocy publicznej ${ }^{11}$.

${ }^{11} \mathrm{~W}$ prawie polskim niektóre instytucje (w szczególności Bankowy Fundusz Gwarancyjny, Krajowy Depozyt Papierów Wartościowych SA) oraz niektóre fundusze (Fundusz Drogowy, Polski Fundusz 
Narodowy Bank Polski dwukrotnie wykupił wyemitowane przez siebie obligacje w celu absorpcji środków, w jakie zasilony został sektor bankowy, po dokonaniu głębokiej redukcji stopy rezerwy obowiązkowej, a więc w warunkach istotnego ograniczenia poziomu nadpłynności sektora bankowego. Pierwszy częściowy wykup (40\% wartości emisji) został przeprowadzony w 2003 r., pozostała część - w 2009 r. Ponadto NBP stosował w okresie 2000-2003 operacje sprzedaży bądź wykupu papierów wartościowych o terminach zapadalności 2, 3, 4, 5 i 10 lat (pochodzące z konwersji niezbywalnych papierów wartościowych Skarbu Państwa będących uprzednio w posiadaniu NBP). Przy wykorzystaniu tego rodzaju operacji polski bank centralny dążył do ograniczenia skali nadpłynności w sektorze bankowym.

Kryzys subprime nie dotknął bezpośrednio polskiego sektora bankowego, ale ograniczył zasilanie utworzonych w Polsce filii zagranicznych korporacji finansowych, ograniczając przejściowo ich płynność. Modyfikacje w zakresie instrumentarium polityki pieniężnej wprowadzone przez NBP jesienią 2008 r., w reakcji na światowy kryzys finansowy, polegały na zastosowaniu czasowo oraz w ograniczonej skali transakcji warunkowych zasilających sektor bankowy w płynność złotową oraz operacji typu ,swap walutowy”, które pozwalają na uzupełnianie przejściowych potrzeb walutowych banków; operacje te zostały całkowicie wstrzymane w $2011 \mathrm{r}$.

Obligacje przedsiębiorstw (obligacje korporacyjne) - obok bonów NBP, nominowanych w złotych bonów i obligacji skarbowych, obligacji komunalnych, obligacji Europejskiego Banku Inwestycyjnego, listów zastawnych oraz obligacji skarbowych nominowanych $\mathrm{w}$ euro - stanowią jedną $\mathrm{z}$ akceptowanych form zabezpieczeń operacji refinansujących, oferowanych przez polski bank centralny. Tego rodzaju papiery wartościowe muszą spełniać kryteria ratingowe ${ }^{12}$, nie mogą być obligacjami sekurytyzowanymi. Ponadto walory te muszą być dopuszczone do obrotu publicznego i wprowadzone do obrotu regulowanego na platformach GPW SA lub BondSpot SA, a wartość nominalna emisji (oznaczona kodem ISIN) powinna wynosić co najmniej $10 \mathrm{mln}$ zł.

Rozwoju) mogą być wyłączone z sektora publicznego. Jednak tego typu podmioty spełniają kryteria instytucji publicznej w świetle prawa europejskiego, toteż nabycie przez NBP na rynku pierwotnym ich obligacji byłoby naruszeniem art. 123 Traktatu o Funkcjonowaniu Unii Europejskiej. Również nabycie na rynku wtórnym takich obligacji mogłoby być uznane za niezgodne z prawem europejskim, chyba że transakcja taka odbywałaby się $\mathrm{w}$ ramach prowadzonej polityki pieniężnej.

${ }^{12}$ Wymóg dotyczy spełnienia jednego z trzech kryteriów ratingowych: obligacja ma rating na poziomie inwestycyjnym; emitent posiada taki rating; obligacje są gwarantowane przez Skarb Państwa lub instytucję finansową posiadającą rating na poziomie inwestycyjnym. 


\section{Zakończenie}

FED, większość banków centralnych Eurosystemu oraz Bank Anglii, prowadzące niekonwencjonalną politykę pieniężną w reakcji na kryzys subprime, wywarły pozytywny wpływ na normalizację sytuacji na rynkach finansowych. Ekspansywna polityka monetarna złagodziła skutki credit crunch, ułatwiła powrót aktywności gospodarczej i złagodziła tendencje deflacyjne w gospodarce światowej. Pozytywna pozostaje także ocena wpływu tej polityki na finanse publiczne, kolejne bowiem transze zakupów papierów skarbowych istotnie obniżyły ich rentowność, a w konsekwencji - także koszty obsługi długu publicznego. Jednak niekonwencjonalna polityka pieniężna, obok doraźnych i średniookresowych korzyści, niesie słabo dotychczas rozpoznane, lecz możliwe do identyfikacji ryzyka, którym trzeba będzie sprostać w przyszłości. Należą do nich m.in.: opóźnienie koniecznych reform finansów publicznych [Roubini, Mihm 2010], nieuzasadniona aprecjacja walut narodowych krajów zaliczanych do rynków wschodzących [Stiglitz 2012, s. 37-39], gwałtowny przyrost agregatów pieniężnych na globalnych rynkach finansowych [Taylor 2012, s. 19; Bernanke 2012; Goodhart, Ashworth 2012, s. 640-670].

Ostateczna ocena niekonwencjonalnej polityki pieniężnej zależeć będzie od umiejętności utrzymywania w długim okresie oczekiwań inflacyjnych na niskim poziomie. W tym zakresie niezbędne wydają się działania zarówno banków centralnych, jak i innych organów nadzorczych i makroostrożnościowych, minimalizujące potencjalne negatywne skutki nadpłynności podmiotów rynku finansowego. Pierwsze kroki już podjęto, ograniczając skalę programów interwencyjnych i redukując sumy bilansowe głównych banków centralnych, a także znacznie podnosząc wymogi kapitałowe i normy ostrożnościowe obowiązujące banki komercyjne.

\section{Literatura}

Ancyparowicz G., 2017, Wybrane aspekty strategii celu inflacyjnego w teorii i praktyce banków centralnych, Annales Universitatis Mariae Curie-Skłodowska, section H - Oeconomia.

Bernanke B.S., 2012, Monetary Policy since the Onset of the Crisis, August 31, https://www.federalreserve.gov/newsevents/speech/bernanke20120831a.htm (1.05.2018).

BIS, 2016, How Have Central Bank Implemented Negative Policy Rates?, Bis Quarterly Review, March 2016.

Cecioni M., Ferrero G., Secchi A., 2011, Unconventional monetary policy in theory and in practice, Bank of Italy Occasional Papers, no. 102.

Decision (EU) 2016/948 of the European Central Bank of 1 June 2016 on the implementation of the corporate sector purchase programme.

Decyzja Rady Prezesów EBC nr 415/98 z 29 czerwca 1998 r. w sprawie konsultacji Europejskiego Banku Centralnego udzielanych władzom krajowym w sprawie projektów przepisów prawnych (98/415/WE). 
Dembinsky P.H., 2012, Finanse po zawale. Od euforii finansowej do gospodarczego ładu, Studio Emka, Warszawa.

EBA, 2016, Risk Assessment of the European Banking System, European Banking Authority, London, December 2016.

ECB, 2016, https://www.ecb.europa.eu/ecb/legal/pdf/celex_32016d0016_en_txt.pdf (28.04.2018).

Goodhart Ch.A.E., Ashworth J.P., 2012, QE: a successful start may be running into diminishing returns, Oxford Review of Economic Policy, vol. 28, Issue 4, 10 December, https://doi.org/10.1093/ oxrep/grs034 (1.05.2018).

Guideline (EU) 2015/510 of the European Central Bank of 19 December 2014 on the implementation of the Eurosystem monetary policy framework (ECB/2014/60), z późn. zm., https://www.ecb.europa. eu/ecb/legal/pdf/celex_02014o0060-20170101_en_txt.pdf (28.04.2018).

Guideline ECB/2007/9, https://www.ecb.europa.eu/ecb/legal/pdf/oj_jol_2014_240_r_0012_en_txt.pdf (28.04.2018)

Guideline of the European Central Bank of 9 July 2014 on additional temporary measures relating to Eurosystem refinancing operations and eligibility of collateral and amending.

Jordan T., 2016, Monetary Policy in the Euro Area's Neighbouring Countries, Safe Policy Center Lectures.

Joyce M., Tong M., Woods R., 2011, The United Kongdom 's quantitative easing policy: design, operation, and impact, Bank of England Quarterly Review Q3, London.

Komunikat Rady Prezesów EBC z dnia 10 marca 2016 r., https://www.ecb.europ.eu/press/pr/date/2 (28.04.2018).

Labonte M., 2012, Monetary Policy and Federal Reserve: Current Policy and Conditions, Congressional Research Service, no. 7-5700.

Lenza M., Pill H., Reichlin L., 2010, Monetary Policy in Exceptional Times, European Central Bank Working Paper Series, no. 1253.

Morgan P., 2009, The Role of Effectiveness of Unconventional Monetary Policy, ADBI Working Papers, no. 163.

NBP, 2017, Programy skupu aktywów realizowane obecnie przez wybrane banki centralne, materiał wewnętrzny NBP, Warszawa.

Philippon T., Reshef A., 2012, Wages and human capital in the US finance industry: 1909-2006, Quarterly Journal of Economics, vol. 127(4).

Quarterly Bulletin 2017 Q3, https://www.bankofengland.co.uk/-/media/boe/files/quarterly-bulletin/2017/cbps-design-operation-and-impact.pdf (28.04.2018).

Roubini N., Mihm S., 2010, Crisis Economics: A Crash Course in the Future of Finance, The Penguin Press, New York.

Stiglitz J.B., 2012, Macroeconomics, monetary policy, and the crisis, [w:] In the Wake of the Crisis: Leading Economists Reassess Economic Policy, eds. O. Blanchard, D. Romer, M. Spencer, J. Stiglitz, MIT Press, Cambridge.

Taylor J.B., 2012, Monetary policy rules work and discretion doesn't: A tale of two eras, Journal of Money, Credit and Banking Lecture, March.

Traktat o Funkcjonowaniu Unii Europejskiej (wersja skonsolidowana) 26.10.2012, Dz. Urz. UE 26.10.2012.

Ustawa z dnia 29 sierpnia 1997 r. o Narodowym Banku Polskim (Dz.U. z 2013, poz. 908 z późn. zm.).

World Bank, 2015, Negative Interest Rates In Europe: A Glance at Their Causes and Implications, Global Economic Prospects, June. 